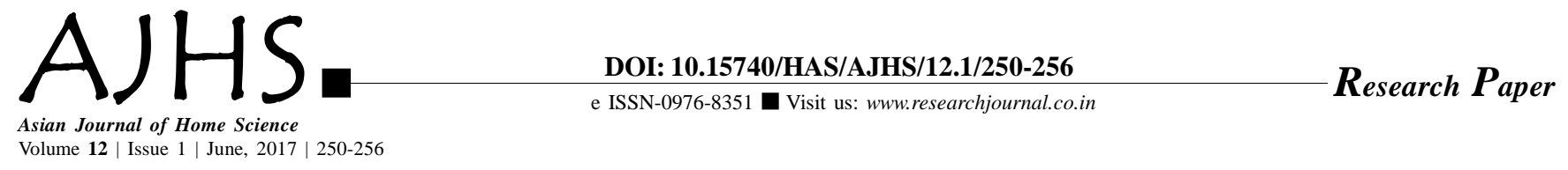

\title{
Utilization of agro waste-okra and its potentiality
}

NABANEETA GOGOI, MINTI GOGOI AND SWAPNA CHOUDHURY

Received: 17.03.2017; Revised: 04.05.2017; Accepted: 20.05.2017

See end of the paper for authors' affiliations

\section{NABANEETA GOGOI}

Department of Textiles and Apparel Designing, Faculty of Home Science, Assam Agricultural University, JORHAT (ASSAM) INDIA

Email : nabaneetagogoi@gmail. com
ABSTRACT : Sustainable use of renewable natural resources is a present day demand. To maintain a ecological balance in the environment, a study was conducted to extract fibre from the waste stem of okra plant and its utilization for making different utility products to fulfil day today needs. The physico-chemical properties such as microscopic structure, IR spectra, length and breadth of fibre, tensile strength, elongation and chemical constituents of bhindi fibre were evaluated. Six different types of products were made and these suitability was tested by a panel of judges and found that the functionality of the developed products were suitable for its intended purpose

KEY WORDS: Extraction, Retting, IR spectra, Non woven, Optimization

- HOW TO CITE THIS PAPER : Gogoi, Nabaneeta, Gogoi, Minti and Choudhury, Swapna (2017). Utilization of agro waste-okra and its potentiality. Asian J. Home Sci., 12 (1) : 250-256, DOI: 10.15740/ HAS/AJHS/12.1/250-256. 